\title{
ANALISIS REGRESI LOGISTIK BINER UNTUK MEMPREDIKSI FAKTOR INTERNAL DAN EKSTERNAL TERHADAP INDEKS PRESTASI
}

\author{
Marna $^{1)}$, Maya Saftari ${ }^{2)}$, Padrul Jana ${ }^{3)}$ Maxrizal $^{4)}$ \\ ${ }_{1,2,4)}$ ISB Atma Luhur, Pangkalpinang \\ ${ }^{3)}$ Universitas PGRI Yogyakarta, Yogyakarta \\ 1)marna@atmaluhur.ac.id, ${ }^{2}$ mayasaftari@atmaluhur.ac.id, ${ }^{3}$ padrul.jana@upy.ac.id, \\ 4)maxrizal@atmaluhur.ac.id
}

\begin{abstract}
Received :

$16 / 11 / 2020$

The logistic linear regression model can be used to determine the chances of students obtaining an grade point below 3.00. Binary logistic regression models can also be used to analyze internal and external factors that are thought to affect

Accepted : student achievement index. Internal factors come from the students themselves,

26/11/2020 while external factors come from the family and society. Research population The population of this study were college students in Pangkalpinang, Bangka Belitung Islands province. Sampling was carried out by cluster sampling based on certain

Published :

21/01/2021 groupings. The method used in this study was a survey of students in universities in Pangkalpinang using a questionnaire. The questionnaire contains $\mathrm{Y}$ variables in the form of achievement index and $\mathrm{X}$ in the form of independent variables, namely father's education, mother's education, monthly allowance, motivation, student attitudes, domicile, gender and study time. Based on these variables, all internal and external factors affect the student achievement index. The percentage of internal and external factors shows the number is above $60 \%$ and the analysis also shows that $37.5 \%$ of the students' GPA is less than 3.00 .
\end{abstract}

Keywords: grade point, biner logistic models, cluster sampling

\begin{abstract}
Abstrak
Model regresi linier logistik dapat digunakan untuk menentukan peluang mahasiswa memperoleh indeks prestasi (IP) di bawah 3,00. Model regresi logistik biner juga bisa digunakan untuk menganalisa faktorfaktor internal dan faktor-faktor eksternal yang diduga mempengaruhi indeks prestasi (IP) mahasiswa. Faktor-faktor intenal berasal dari mahasiswanya sendiri, sedangkan faktor eksternal berasal dari lingkungan keluarga dan masyarakat. Populasi penelitian Populasi penelitian ini adalah mahasiswa perguruan tinggi yang ada di Pangkalpinang propinsi Kepulauan Bangka Belitung. Pengambilan sampel dilakukan dengan cluster sampling berdasarkan pengelompokan tertentu. Metode yang digunakan dalam penelitian ini adalah survei terhadap mahasiswa-mahasiswa di perguruan tinggi yang ada di Pangkalpinang dengan menggunakan kuisioner. Kuisioner berisi variabel $\mathrm{Y}$ berupa indeks prestasi dan $\mathrm{X}$ berupa variabelvariabel bebas yaitu pendidikan ayah, pendidikan ibu,uang saku setiap bulan, motivasi, sikap mahasiswa, domisili, jenis kelamin dan waktu belajar. Berdasarkan variabel- variabel tersebut, semua faktor internal dan eksternal mempengaruhi indeks prestasi mahasiswa. Persentase faktor internal dan eksternal menunjukkan angka di atas $60 \%$ dan dari analisa juga diperoleh hasil penel.
\end{abstract}

Kata Kunci: Indeks Prestasi, Regresi Logistik Biner, Cluster Sampling

\section{Pendahuluan}

Nilai rata-rata tiap semester yang diperoleh mahasiswa dalam proses belajar mengajar biasa disebut dengan indeks prestasi (IP). Diduga ada faktor-faktor yang mempengaruhi indeks prestasi mahasiswa tersebut. Penelitian ini dilakukan untuk mencari solusi dari permasalahan pendugaan faktor-faktor yang mempengaruhi IP mahasiswa. Faktor-faktor ini dapat berasal dari internal maupun eksternal. Faktor internal 
dapat berasal dari mahasiswanya sendiri, sedangkan faktor eksternal dapat berasal dari lingkungan keluarga dan masyarakat.

Menurut Widia, H. (2018), di jelaskan bahwa lingkungan keluarga merupakan lingkungan pertama seorang anak atau peserta didik untuk belajar. Dari hasil penelitian disimpulkan bahwa faktor eksternal yaitu lingkungan keluarga memberikan pengaruh yang sangat besar terhadap hasil belajar, kemudian faktor kedua adalah lingkungan masyarakat.(Hapnita, 2018)

Penelitian lain yang dilakukan oleh Safitri, dkk (2013) dengan judul "FaktorFaktor Yang Mempengaruhi Indeks Prestasi Mahasiswa FSM Universitas Diponegoro Semester Pertama Dengan Motode Regresi Logistik Biner", disimpulkan bahwa faktor nilai ujian nasional serta faktor eksternal yaitu hubungan dengan teman mempunyai hubungan yang signifikan. (Safitri Daruyani, Yuciana Wilandari, 2013)

Sejalan dengan penelitian Tampil (2017), menyimpulkan bahwa program studi dan tempat tinggal berpeluang memiliki pengaruh terhadap Indeks Prestasi Kumulatif (IPK). (Tampil et al., 2017)

Penelitian oleh Setyawati, dkk ( 2020), menyatakan bahwa faktor eksternal berupa pemilihan jurusan sewaktu SMU dan dari mana mahasiswa berasal mempengaruhi nilai indeks prestasi. (Setyawati et al., 2020)

Penelitian E. Ahani (2010), menyatakan bahwa semua variabel yang diteliti signifikan terhadap indeks prestasi. (Ahani et al., 2010)

Faktor-faktor yang diduga mempengaruhi IP dapat di analisis secara statistik dengan menggunakan analisis regresi. Analisis regresi merupakan metode statistik yang sering digunakan untuk memodelkan hubungan antara variabel independent dan variabel dependent. (Saidah et al., 2016)

Metode penelitian yang digunakan adalah metode regresi logistik biner. Menurut Basuki (2018) dan Hadjar (2018) regresi logistik adalah suatu cara yang dapat digunakan untuk mendapatkan dugaan nilai (skor) kriteria suatu variabel, pemodelan dengan regresi logistik menghasilkan taksiran probabilitas munculnya peristiwa (skor 1) pada variabel kriteria. (Basuki, 2018) dan (Hadjar, 2018).

Populasi penelitian ini adalah mahasiswa perguruan tinggi yang ada di Pangkalpinang propinsi Kepulauan Bangka Belitung. Pengambilan sampel dilakukan dengan cluster sampling berdasarkan pengelompokan tertentu. Cluster sampling merupakan teknik memilih kelompok dari unit-unit kecil. (Ningsih \& Widiharto, 2014) 
Analisis data yang digunakan berupa analisis deskriptif dan analisis Regresi Logistik. Menurut Wahyudi (2016), analisis deskriptif dapat digunakan untuk menggambarkan peran hubungan antara masing-masing variabel yaitu variabel bebas dengan variabel terikatnya. (Wahyudi, 2016)

Variabel yang diamati diantaranya adalah pendidikan ayah, pendidikan ibu, biaya hidup setiap bulan, motivasi, tempat tinggal, sikap, jenis kelamin, dan lama belajar. Penelitian ini juga bertujuan untuk mengetahui berapa besar peluang mahasiswa memperoleh IP dibawah 3, berdasarkan model yang diperoleh masing-masing faktor yang signifikan.

\section{Metode Penelitian}

\subsection{Metodologi Penelitian}

\subsubsection{Data}

Metode yang digunakan dalam penelitian ini adalah survei terhadap mahasiswa-mahasiswa di perguruan tinggi yang ada di Pangkalpinang. Langkah-langkah yang dilakukan dalam pengumpulan data yaitu 1) pembuatan kuisioner penelitian, kuisioner berisi beberapa pertanyaan yang terdiri dari pendidikan ayah, pendidikan ibu, uang saku setiap bulan, motivasi, sikap, domisili mahasiswa, jenis kelamin dan waktu belajar. 2) Melakukan pengujian validitas dan reabilitas kuisioner untuk variabel motivasi dan sikap mahasiswa. 3) pengumpulan data, data primer yang diperoleh melalui kuisioner yang sudah diisi mahasiswa. Data diambil dengan teknik sampling yaitu pengambilan sampel berdasarkan kelompok tertentu.

\subsection{Variabel Penelitian}

a. Variabel $\mathrm{Y}=$ Indeks Prestasi (variabel dependent) pengkategorian yaitu

$Y: 0$, IP kurang dari 3,00

$Y: 1$, IP lebih dari sama dengan 3,00

b. Variabel bebas ( variabel independent) yang diamati terdiri dari beberapa variabel yaitu:

1. Pendidikan Ayah $\left(X_{1}\right)$ dengan skala ordinal, pengkategoriannya: Tidak Sekolah (0), Sekolah Dasar (1), SMP (2), SMA (3), Sarjana(4). 
2. Pendidikan Ibu $\left(X_{2}\right)$ dengan skala ordinal, pengkategoriannya: Tidak Sekolah (0), Sekolah Dasar (1), SMP (2), SMA (3), Sarjana(4).

3. Uang Saku $\left(X_{3}\right)$ dengan skala ordinal, pengkategoriannya: Kurang dari 1 juta (0), 1 juta sampai dengan 2 juta (1), di atas 2 juta (2).

4. Waktu Belajar $\left(X_{4}\right)$ dengan skala ordinal, pengkategoriannya : Kurang dari 7 jam (0), lebih dari sama dengan7 jam (1).

5. Motivasi $\left(X_{5}\right)$ dengan skala ordinal, pengkategoriannya : Rendah (0), Sedang(1), Tinggi(2).

6. Sikap Mahasiswa ( $X_{6}$ ), pengkategorianya : Tidak Baik (0), Baik (1).

7. Domisili mahasiswa $\left(X_{7}\right)$, pengakategoriannya: Kost (0), Tinggal dengan orangtua(1).

8. Jenis Kelamin Mahasiswa $\left(X_{8}\right)$. dengan skala nominal, pengkategoriannnya: Perempuan (0, laki - laki (1).

\subsection{Analisis Data}

1. Melakukan analisis deskriptif yang bertujuan untuk mendapatkan karakteristik terhadap variabel-variabel yang diamati.

2. Melakukan analisis inferensia yaitu analisis regresi logistik. Model regresi logistik secara umum adalah sebagai berikut:

$\pi(X)=\frac{\exp \left(\beta_{0}+\beta_{1} X_{1}+\beta_{2} X_{2}+\beta_{3} X_{3}+\beta_{4} X_{4}+\beta_{5} X_{5}+\beta_{6} X_{6}+\beta_{7} X_{7}+\beta_{8} X_{8}\right)}{1+\exp \left(\beta_{0}+\beta_{1} X_{1}+\beta_{2} X_{2}+\beta_{3} X_{3}+\beta_{4} X_{4}+\beta_{5} X_{5}+\beta_{6} X_{6}+\beta_{7} X_{7}+\beta_{8} X_{8}\right)}$

Keterangan:

$\pi(X)=$ peluang seorang mahasiswa memperoleh IP kurang dari 3.

$\beta_{0}$ : konstanta

$\beta_{i}$ : koefisien regresi logistik variabel bebas ke $-i . i=1,2, \ldots, 8$

$X_{1}:$ Pendidikan Ayah

$X_{2}:$ Pendidikan Ibu

$X_{3}$ : Uang Saku

$X_{4}$ : Waktu belajar

$X_{5}$ : Motivasi Mahasiswa

$X_{6}$ : Sikap Mahasiswa 


$$
\begin{aligned}
& X_{7} \text { : Domisili Mahasiswa } \\
& X_{8}=\text { Jenis Kelamin }
\end{aligned}
$$

3. Melakukan pengujian model regresi logistik
a. Pengujian Secara Simultan
b. Pengujian Secara Parsial

4. Melakukan pemilihan model terbaik untuk Indeks prestasi mahasiswa

5. Menginterpretasikan model

6. Membuat kesimpulan dan saran hasil penelitian

\section{Hasil dan Pembahasan}

Data yang akan dianalisis dalam penelitian ini sebanyak 120 sampel yang diperoleh dari data kuesioner, karakteristik dari mahasiswa di Pangkalpinang angkatan 2018 disajikan pada Tabel 1 berikut:

Tabel 1. Karakteristik Mahasiswa Pangkalpinang angkatan 2018

\begin{tabular}{llcc}
\hline \multicolumn{1}{c}{ Variabel } & \multicolumn{1}{c}{ Kategori } & Jumlah & Persentase(\%) \\
\hline Total Sampel & & 120 & \\
\hline Pendidikan Ayah & Tidak Sekolah (0) & 33 & 27,5 \\
& Sekolah Dasar (1) & 29 & 24,2 \\
& SMP (2) & 18 & 15,0 \\
& SMA (3) & 32 & 26,7 \\
& Sarjana (4) & 8 & 6,6 \\
\hline Pendidikan Ibu & Tidak Sekolah (0) & 27 & 22,5 \\
& Sekolah Dasar (1) & 24 & 20,0 \\
& SMP (2) & 12 & 10,0 \\
& SMA (3) & 49 & 40,8 \\
& Sarjana (4) & 8 & 6,7 \\
\hline Uang Saku & Kurang dari 1 juta (0) & 74 & 61,7 \\
& 1 juta sampai 2 juta(1) & 24 & 20,0 \\
& Lebih dari 2 juta(2) & 22 & 18,3 \\
\hline Waktu belajar & < 7 jam (0) & 52 & 43,3 \\
& $\geq 7$ jam (1) & 68 & 56,7 \\
\hline Motivasi & Tinggi (0) & 68 & 56,7 \\
& Sedang (1) & 40 & 33,3 \\
& Rendah (2) & 12 & 10,0 \\
\hline Sikap & Tidak baik (0) & 79 & 65,8 \\
& Baik (1) & 41 & 34,2 \\
\hline Domisili Mahasiswa & Kost (0) & 46 & 38,3 \\
& Tinggal dengan orang & & \\
& tua (1) & 74 & 61,7 \\
\hline Jenis Kelamin & Perempuan (0) & 51 & 42,5 \\
& & &
\end{tabular}




\begin{tabular}{llcc}
\hline \multicolumn{1}{c}{ Variabel } & \multicolumn{1}{c}{ Kategori } & Jumlah & Persentase(\%) \\
\hline & Laki-laki (1) & 69 & 57,5 \\
\hline IPK & IPK $<3(0)$ & 45 & 37,5 \\
(Variabel Respon) & IPK $\geq 3(1)$ & 75 & 62,5 \\
\hline
\end{tabular}

Dari tabel 1 di atas, menunjukkan sebesar 37,5\% dari 120 mahasiswa Pangkalpinang angkatan 2018 memperoleh IPK kurang dari 3,00. 40,8\% mahasiswa berasal dari ibu yang pendidikan terakhirnya SMA. 61,7\% mahasiswa mendapat uang sakunya di bawah 1 juta, sebanyak 56,7\% waktu belajar mahasiswa per minggunya lebih dari 7 jam. Sikap mahasiswa $65,8 \%$ sudah baik dan motivasinya juga tinggi. $61,7 \%$ mahasiswa tinggal bersama dengan orangtua selama kuliah dan berdasarkan jenis kelamin mahasiswa di pangkalpinang angkatan 2018 lebih banyak laki-laki dibandingkan dengan perempuan yaitu sebanyak $57,5 \%$.

Dalam penelitian ini terdapat variabel terikat yang terdiri dari 2 kategori yaitu IPK kurang dari 3 dan IPK lebih dari sama dengan 3. Variabel-variabel bebas yang diamati seperti pada tabel 1 dapat dilihat hubungannya dengan variabel terikat melalui tabel-tabel kontingensi berikut.

Tabel 2. Hubungan antara IPK dengan Pendidikan Ibu

\begin{tabular}{llrrr}
\hline & & \multicolumn{3}{c}{ IPK } \\
\hline Pendidikan Ibu & Tidak Sekolah & 14 & 13 & 27 \\
\cline { 2 - 4 } & & $51,8 \%$ & $48.2 \%$ & $100.0 \%$ \\
\cline { 2 - 4 } & Sekolah Dasar & 2 & 22 & 24 \\
\cline { 2 - 4 } & SMP & $8.3 \%$ & $91.7 \%$ & $100.0 \%$ \\
\cline { 2 - 4 } & & 4 & 8 & 12 \\
\cline { 2 - 4 } & SMA & $21.3 \%$ & $66.7 \%$ & $100.0 \%$ \\
\cline { 2 - 4 } & & $42.9 \%$ & $57.1 \%$ & $100.0 \%$ \\
\cline { 2 - 4 } & Sarjana & 4 & 49 \\
\hline
\end{tabular}

Hasil pada Tabel 2 menunjukkan bahwa pada variabel pendidikan ibu dengan kategori tidak sekolah, 51,8\% mahasiswa memperoleh IPK kurang dari 3, artinya lebih banyak jika dibaandingkan dengan yang memperoleh IPK lebih dari 3 yaitu sebanyak $48,2 \%$. 
Tabel 3 . Hubungan antara IPK dengan Motivasi

\begin{tabular}{|c|c|c|c|c|}
\hline & & \multicolumn{2}{|c|}{ IPK } & \multirow[b]{2}{*}{ Total } \\
\hline & & $<3$ & $\geq 3$ & \\
\hline \multirow[t]{6}{*}{ Motivasi } & Tinggi & 23 & 45 & 68 \\
\hline & & $33.8 \%$ & $66.2 \%$ & $100.0 \%$ \\
\hline & Sedang & 20 & 20 & 40 \\
\hline & & $50.0 \%$ & $50.0 \%$ & $100.0 \%$ \\
\hline & Rendah & 2 & 10 & 12 \\
\hline & & $16.7 \%$ & $83.3 \%$ & $100.0 \%$ \\
\hline \multirow{2}{*}{\multicolumn{2}{|c|}{ Total }} & 45 & 75 & 120 \\
\hline & & $37.5 \%$ & $62.5 \%$ & $100.0 \%$ \\
\hline
\end{tabular}

Hasil pada Tabel 3 menunjukkan bahwa 66,2\% mahasiswa memperoleh IPK lebih dari 3 memiliki motivasi yang tinggi dalam dirinya dan 33,8\% nya memperoleh IPK kurang dari 3. Akan tetapi, mahasiswa yang memiliki motivasi rendah juga banyak memperoleh IPK lebih dari 3 yaitu 83,3\%. Hal ini lebih banyak dibandingkan dengan memperoleh IPK kurang dari 3 (16,7\%).

Tabel 4. Hubungan antara IPK dengan Sikap

\begin{tabular}{|c|c|c|c|c|}
\hline & & \multicolumn{2}{|c|}{ IPK } & \multirow[b]{2}{*}{ Total } \\
\hline & & $<3$ & $\geq 3$ & \\
\hline \multirow[t]{4}{*}{ Sikap } & Tidak Baik & 39 & 40 & 79 \\
\hline & & $49.4 \%$ & $50.6 \%$ & $100.0 \%$ \\
\hline & Baik & 6 & 35 & 41 \\
\hline & & $14.6 \%$ & $85.4 \%$ & $100.0 \%$ \\
\hline \multirow[t]{2}{*}{ Total } & & 39 & 75 & 120 \\
\hline & & $37.5 \%$ & $62.5 \%$ & $100.0 \%$ \\
\hline
\end{tabular}

Pada Tabel 4, menunjukkan bahwa 85,4\% mahasiswa memperoleh IPK lebih dari 3 memiliki sikap yang baik dalam dirinya dan $14,6 \%$ nya memperoleh IPK kurang dari 3. Mahasiswa yang memiliki sikap yang tidak baik juga lebih banyak memperoleh IPK lebih dari 3 (50,6\%) dibandingkan dengan memperoleh IPK kurang dari 3 (49,4\%).

\subsection{Model regresi Logistik}

Dalam penelitian ini untuk mengetahui faktor-faktor yang berpengaruh secara signifikan terhadap Indeks Prestasi Mahasiswa digunakan regresi logistik. Berdasarkan variabel-variabel yang signifikan tersebut, maka dapat diketahui peluang seseorang akan memperoleh Indeks Prestasi kurang dari 3,00 atau lebih dari 3,00. 
Dalam regresi logistik setelah diperoleh model terbaik, maka untuk melihat bahwa model yang diperoleh tersebut signifikan secara simultan dapat dilihat berdasarkan nilai statistik uji G. Selain itu, dalam model juga terdapat nilai koefisien yang menunjukkan berapa besar pengaruh variabel bebas terhadap variabel terikat. Untuk mengetahui variabel bebas tersebut secara parsial berpengaruh nyata atau tidak terhadap model, dapat dilihat dari nilai P-value (sig.). Variabel bebas berpengaruh nyata terhadap model jika nilai $p$-value variabel bebas tersebut kurang dari taraf nyata $\alpha$, dalam hal ini $\alpha=0,05$. Model yang diperoleh adalah sebagai berikut:

Tabel 5. Model Terbaik Indeks Prestasi Mahasiswa

\begin{tabular}{lccrr}
\hline Variabel & B & \multicolumn{1}{c}{ SE } & \multicolumn{1}{c}{ Sig. } & Exp(B) \\
\hline Konstanta & 3.134 & 1.453 & .031 & 22.966 \\
$X_{1}:$ Pendidikan Ayah & & & .140 & \\
$X_{1}: 1$ & -2.517 & 1.367 & .066 & .081 \\
$\mathrm{X}_{1}: 2$ & -2.780 & 1.345 & .039 & .062 \\
$\mathrm{X}_{1}: 3$ & -1.540 & 1.336 & .249 & .214 \\
$\mathrm{X}_{1}: 4$ & -1.245 & 1.268 & .326 & .288 \\
$\mathrm{X}_{2}:$ Pendidikan Ibu & & & .036 & \\
$\mathrm{X}_{2}: 1$ & -.121 & 1.207 & .920 & .886 \\
$\mathrm{X}_{2}: 2$ & 2.953 & 1.261 & .019 & 19.158 \\
$\mathrm{X}_{2}: 3$ & .346 & 1.199 & .773 & 1.413 \\
$\mathrm{X}_{2}: 4$ & .047 & .967 & .961 & 1.048 \\
$\mathrm{X}_{4}:$ Waktu belajar (1) & 1.549 & .543 & .004 & 4.705 \\
$\mathrm{X}_{6}:$ Sikap (1) & -2.384 & .648 & .000 & .092 \\
\hline
\end{tabular}

Hasil analisis diperoleh nilai p-value uji $\mathrm{G}$ sebesar $0,007<0,05$ hal ini menunjukkan bahwa model yang diperoleh signifikan secara simultan. Artinya model yang diperoleh sesuai dengan data yang dianalisis. Selanjutnya untuk pengujian secara parsial terhadap variabel bebas diperoleh varaibel sikap, pendidikan ibu, pendidikan ayah, dan lama belajar memberikan nilai uji Wald yang semuanya signifikan ( nilai sig < 0,05). Sehingga variabel bebas tersebut dapat digunakan dalam menduga peluang mahasiswa mendapat IPK dibawah 3,00.

Berdasarkan Tabel 5, diperoleh model regresi logistik sebagai berikut :

$$
\pi(X)=\frac{\exp \left(3,1-2,5 X_{1(1)}-2,7 X_{1(2)}-1,5 X_{1(3)}-1,2 X_{1(4)}-0,12 X_{2(1)}+2,9 X_{2(2)}+0,3 X_{2(3)}+0,04 X_{2(4)}+1,5 X_{4(1)}-2,3 X_{6(1)}\right)}{1+\exp \left(3,1-2,5 X_{1(1)}-2,7 X_{1(2)}-1,5 X_{1(3)}-1,2 X_{1(4)}-0,12 X_{2(1)}+2,9 X_{2(2)}+0,3 X_{2(3)}+0,04 X_{2(4)}+1,5 X_{4(1)}-2,3 X_{6(1)}\right)}
$$

Berdasarkan model yang diperoleh maka variabel bebas yang berpengaruh nyata terhadap IPK amahasisw adalah sikap, pendidikan ibu, pendidikan ayah, dan waktu 
belajar. Untuk melihat besar peluang seseorang untuk memperoleh IPK kurang dari 3,00 atau lebih dari 3,00, dapat dilakukan dengan cara menghitung contoh berikut:

Misalkan, seorang mahasiswa memiliki ayah yang lulusannya juga SMP, ibu yang pendidikannya lulusan SMA, waktu belajar lebih dari 7 jam, dan mahasiswanya bersikap baik maka berdasarkan karakteristik tersebut didapat model peluang mahasiswa tersebut akan mendapatkan IPK dibawah 3 sebagai berikut :

$$
\begin{gathered}
\pi(\mathrm{X})=\frac{\exp \left(3,1-2,5 X_{1(1)}-2,7 X_{1(2)}-1,5 X_{1(3)}-1,2 X_{1(4)}-0,12 X_{2(1)}+2,9 X_{2(2)}+0,3 X_{2(3)}+0,04 X_{2(4)}+1,5 X_{4(1)}-2,3 X_{6(1)}\right)}{1+\exp \left(3,1-2,5 X_{1(1)}-2,7 X_{1(2)}-1,5 X_{1(3)}-1,2 X_{1(4)}-0,12 X_{2(1)}+2,9 X_{2(2)}+0,3 X_{2(3)}+0,04 X_{2(4)}+1,5 X_{4(1)}-2,3 X_{6(1)}\right)} \\
\pi(\mathrm{X})=\frac{\exp (3,1-2,7+0,3+1,5-2,3)}{1+\exp (3,1-2,7+0,3+1,5-2,3)} \\
\pi(\mathrm{X})=\frac{\exp (-0,1)}{1+\exp (-0,1)}=\frac{0,9}{1+0,9}=0,47
\end{gathered}
$$

Berdasarkan perhitungan tersebut diperoleh besarnya peluang seorang mahasiswa yang memiliki ayah yang lulusannya juga SMP, ibu yang pendidikannya lulusan SMA, waktu belajar lebih dari 7 jam, dan mahasiswanya bersikap baik untuk memperoleh IPK dibawah 3 adalah sebesar 0,47 atau $47 \%$, dan peluang mahasiswa tersebut untuk memperoleh IPK lebih dari 3 adalah 0,53 atau $53 \%$

\section{Kesimpulan}

Dari hasil penelitian diperoleh bahwa persentase mahasiswa angkatan $2018 \mathrm{di}$ pangkalpinang yang memperoleh IPK kurang dari 3,00 sebanyak 37,5\% . Pendidikan terakhir orang tua mahasiswa yang paling banyak adalah lulusan SLTA. 61,7\% mahasiswa biaya hidupnya di bawah 1 juta, sebanyak 56,7\% lama belajar mahasiswa per minggunya diatas 7 jam. Sikap mahasiswa $65,8 \%$ sudah baik dan motivasinya juga tinggi. $61,7 \%$ mahasiswa tinggal bersama dengan orangtua selama kuliah dan berdasarkan jenis kelamin mahasiswa di pangkalpinang angkatan 2018 lebih banyak laki-laki dibandingkan dengan perempuan yaitu sebanyak 57,5\%. Model IPK mahasiswa angkatan 2018 di Pangkalpinang yang diperoleh adalah

$$
\pi(X)=\frac{\exp \left(3,1-2,5 X_{1(1)}-2,7 X_{1(2)}-1,5 X_{1(3)}-1,2 X_{1(4)}-0,12 X_{2(1)}+2,9 X_{2(2)}+0,3 X_{2(3)}+0,04 X_{2(4)}+1,5 X_{4(1)}-2,3 X_{6(1)}\right)}{1+\exp \left(3,1-2,5 X_{1(1)}-2,7 X_{1(2)}-1,5 X_{1(3)}-1,2 X_{1(4)}-0,12 X_{2(1)}+2,9 X_{2(2)}+0,3 X_{2(3)}+0,04 X_{2(4)}+1,5 X_{4(1)}-2,3 X_{6(1)}\right)}
$$

\section{Pustaka}

Ahani, E., Abass, O., \& Okafor Ray, O. (2010). Application of Logistic Regression Model to Graduating CGPA of University Graduates. Journal of Modern Mathematics and Statistics. https://doi.org/10.3923/jmmstat.2010.58.62 
Basuki, A. T. (2018). Regresi Logistik Biner. Jurnal Pendidikan MIPA.

Hadjar, I. (2018). Regresi Logistik. Phenomenon : Jurnal Pendidikan MIPA.

Hapnita, W. dkk. (2018). Faktor Internal Dan Eksternal Yang Dominan Mempengaruhi Hasil Belajar Menggambar Dengan Perangkat Lunak Siswa Kelas XI Teknik Gambar Bangunan SMK N 1 Padang Tahun 2016/2017. CIVED (Journal of Civil Engineering and Vocational Education), 5(1), 2175-2182. https://doi.org/10.24036/cived.v5i1.9941

Ningsih, B. M., \& Widiharto, C. A. (2014). Cluster Random Sampling . Jurnal Bimbingan Dan Konseling.

Safitri Daruyani, Yuciana Wilandari, H. Y. (2013). Faktor-faktor yang mempengaruhi indeks prestasi mahasiswa fsm universitas diponegoro semaster pertama dengan motode regresi logistik biner. Prosiding Seminar Nasional Statistika.

Saidah, Yanuar, F., \& Devianto, D. (2016). Analisis Regresi Analisis Regresi. Jurnal Matematika UNAND.

Setyawati, D. U., Korida, B. D., \& Febrilia, B. R. A. (2020). Analisis Regresi Logistik Ordinal Faktor-Faktor yang Mempengaruhi IPK Mahasiswa. Jurnal Varian. https://doi.org/10.30812/varian.v3i2.615

Tampil, Y., Komaliq, H., \& Langi, Y. (2017). Analisis Regresi Logistik Untuk Menentukan Faktor-Faktor Yang Mempengaruhi Indeks Prestasi Kumulatif (IPK) Mahasiswa FMIPA Universitas Sam Ratulangi Manado. D'CARTESIAN. https://doi.org/10.35799/dc.6.2.2017.17023

Wahyudi, W. (2016). ANALISIS KONTRIBUSI SIKAP ILMIAH, MOTIVASI BELAJAR DAN KEMANDIRIANBELAJAR TERHADAP PRESTASI BELAJAR MAHASISWA PRODI PENDIDIKAN FISIKA STKIP PGRI PONTIANAK. Jurnal Edukasi Matematika Dan Sains. https://doi.org/10.25273/jems.v1i2.123 